\title{
QUEEN'S
UNIVERSITY
BELFAST
}

\section{A design of a fixed bed plasma DRIFTS cell for studying the NTP- assisted heterogeneously catalysed reactions}

Stere, C., Chansai, S., Gholami, R. G., Wangkawong, K., Singhania, A., Goguet, A., Inceesungvorn, B., \& Hardacre, C. (2020). A design of a fixed bed plasma DRIFTS cell for studying the NTP-assisted heterogeneously catalysed reactions. CATALYSIS SCIENCE \& TECHNOLOGY. https://doi.org/10.1039/D0CY00036A

\section{Published in: \\ CATALYSIS SCIENCE \& TECHNOLOGY}

\section{Document Version:}

Peer reviewed version

Queen's University Belfast - Research Portal:

Link to publication record in Queen's University Belfast Research Portal

\section{Publisher rights}

Copyright 2020 RSC. This work is made available online in accordance with the publisher's policies. Please refer to any applicable terms of use of the publisher.

\section{General rights}

Copyright for the publications made accessible via the Queen's University Belfast Research Portal is retained by the author(s) and / or other copyright owners and it is a condition of accessing these publications that users recognise and abide by the legal requirements associated with these rights.

Take down policy

The Research Portal is Queen's institutional repository that provides access to Queen's research output. Every effort has been made to ensure that content in the Research Portal does not infringe any person's rights, or applicable UK laws. If you discover content in the Research Portal that you believe breaches copyright or violates any law, please contact openaccess@qub.ac.uk. 
Received 00th January 20xx, Accepted 00th January 20xx DOI: $10.1039 / x 0 x \times 00000 x$

\title{
A design of a fixed bed plasma DRIFTS cell for studying the NTP- assisted heterogeneously catalysed reactions
}

\author{
Cristina Stere ${ }^{1}$, Sarayute Chansai $^{1}$, Rahman Gholami $^{1}$, Kanlayawat Wangkawong ${ }^{1,2}$, Amit \\ Singhania ${ }^{1}$, Alexandre Goguet ${ }^{3}$, Burapat Inceesungvorn ${ }^{2}$, Christopher Hardacre ${ }^{1, *}$
}

\begin{abstract}
A newly developed diffuse reflectance infra-red Fourier transform spectroscopy (DRIFTS) cell for the in-situ study of nonthermal plasma (NTP)-assisted heterogeneously catalysed reactions is presented and evaluated using methane oxidation over a $\mathrm{Pd} / \mathrm{Al}_{2} \mathrm{O}_{3}$ catalyst. By using the new fixed bed plasma DRIFTS cell coupled with mass spectrometry, the NTP discharge is generated inside the catalyst bed and allows simultaneous, in-situ DRIFTS analysis to be undertaken. The spectroscopy has revealed that the formation of surface species, e.g. formate and carbonate, is significantly influenced by NTP generation under methane oxidation conditions at different voltages when comparing with the conventionally thermal activation. During the NTP-DRIFTS-MS measurements, it is also found that there is no signal interference between IR beam and plasma plume, making this a viable DRIFTS system for studying the plasma catalysis.
\end{abstract}

\section{Introduction}

Non-thermal plasma (NTP) assisted catalytic processes have been extensively studied due to the interest in applying them in industrial, environmental and medical fields of research ${ }^{1-12}$, especially pollution control ${ }^{13-19}$ and surface decontamination ${ }^{20,21}$. In comparison to traditional thermally activated catalytic processes, NTP technology can provide an alternative way to promote catalytic reactions using highly reactive species such as free radicals, charged ions, atoms, excited molecules and electrons, formed in the plasma discharge by the dissociation of gas molecules in the reaction feed. These processes then initiate the chemical reactions to convert reactants to the desirable products. Importantly, the NTP activates the reactions at relatively low temperatures enhancing their kinetics ${ }^{22,23}$. Amongst the most commonly studied types of plasma, the dielectric barrier discharge (DBD) offers the advantages of easy implementation of the catalyst within the reactor, stability and convenience for several applications ${ }^{3}$.

Recently, Stere and co-workers reported the development of a plasma reactor coupled with diffuse reflectance infrared Fourier transform spectroscopy (DRIFTS) for the water gas shift reaction ${ }^{24}$ and the selective catalytic reduction of $\mathrm{NO}_{x}$ with hydrocarbon (HC$\mathrm{SCR})^{25}$. This setup provided insight into the surface processes during the NTP promotion of the catalytic activity. However, the flow configuration within this DRIFTS reactor system was different from

\footnotetext{
a. Department of Chemical Engineering and Analytical Science, The University of Manchester, Manchester M13 9PL, U.K.

b. Graduate School, Department of Chemistry, Centre of Excellence in Materials Science and Technology, Faculty of Science, Chiang Mai University, Chiang Ma 50200, Thailand

c. School of Chemistry and Chemical Engineering, The Queen's University of Belfast, David Keir Building, Stranmillis Road, Belfast BT9 5AG, U.K.

*Corresponding author: c.hardacre@manchester.ac.uk

Electronic Supplementary Information (ESI) available: See

DOI: $10.1039 / x 0 x x 00000 x$
}

that of a plug flow reactor typically utilised for many such reactions since it consisted of a plasma jet of the gas feed being directed at the surface of the catalyst within the DRIFTS crucible ${ }^{25}$. In order to simultaneously measure and correlate the spectroscopic and kinetic data under plasma conditions, it is important that the plasma discharge is formed inside the catalyst bed in order to better match the catalytic reaction measurements within a normal plug flow reactor.

The design and application of a fixed bed plasma DRIFTS cell for studying the NTP-assisted heterogeneously catalysed reactions is presently reported. To test and evaluate the performance of this newly-developed plug flow type NTP-DRIFTS system, methane oxidation over $\mathrm{Pd} / \mathrm{Al}_{2} \mathrm{O}_{3}$ catalyst has been investigated. Methane is difficult to oxidise due to its high $\mathrm{C}-\mathrm{H}$ bond strength and many researchers have investigated methane oxidation under thermal conditions. Relatively high temperatures are usually required to oxidise methane even over Pt and Pd catalysts ${ }^{26}$ especially in the presence of water. However, it has been reported that Pd-based catalysts are promising for methane oxidation ${ }^{25-28}$, with their activity being strongly dependent on the nature of the support used (e.g. $\gamma-\mathrm{Al}_{2} \mathrm{O}_{3}, \mathrm{TiO}_{2}, \mathrm{ZrO}_{2}, \mathrm{MgO}, \mathrm{MCM}-41, \mathrm{CO}_{2} \mathrm{O}_{3}$ ) ${ }^{29-33}$. Among these catalysts, $\mathrm{Pd} / \mathrm{Al}_{2} \mathrm{O}_{3}$ has been reported to be the most effective candidate for this particular reaction.

Several studies have investigated and attempted to better understand the mechanism of methane oxidation and the nature of the surface species and Pd active sites using in-situ DRIFTS, in-situ XPS, in-situ XRD and DFT calculations ${ }^{33-39}$. However, the detailed mechanism of this reaction is still under debate. Li et al. ${ }^{38}$ have reported that $\mathrm{O}_{2}$ can easily adsorb on $\mathrm{Pd} / \mathrm{Al}_{2} \mathrm{O}_{3}$ and $\mathrm{Pd} / \mathrm{CO}_{3} \mathrm{O}_{4}$ to form reactive species, subsequently interacting with $\mathrm{CH}_{4}$ to form formate $\left(\mathrm{HCOO}^{-}\right)$and carbonate $\left(\mathrm{CO}_{3}{ }^{-}\right)$intermediates, which can decompose to $\mathrm{CO}$ and $\mathrm{CO}_{2}$, respectively. $\mathrm{Na}$ et al. ${ }^{33}$ investigated the influence of $\mathrm{Zr}$ doping on the $\mathrm{Pd} / \mathrm{Al}_{2} \mathrm{O}_{3}$ catalyst and found that its addition enhanced the number of oxygen vacancies subsequently promoting the activation of gaseous oxygen and the oxidation of 
formate ions to carbonate ions, which in turn improved the oxidation of methane over the $\mathrm{Pd} / \mathrm{Al}_{2} \mathrm{O}_{3}$ catalyst.

Ciuparu and co-authors 30 have investigated the surface hydroxyls during methane oxidation over $\mathrm{Pd} / \gamma-\mathrm{Al}_{2} \mathrm{O}_{3}$ and reported the direct evidence for their formation and accumulation. They also found that hydroxyl groups derived from the dissociation of water on fully-oxidised PdO produced lower coverage than those derived from the methane dissociation on surface PdO species. They also proposed a dehydroxylation mechanism to form gas phase $\mathrm{H}_{2} \mathrm{O}$.

Schmal et al. ${ }^{35}$ performed in-situ XPS and DRIFTS measurements under methane oxidation conditions over different $\mathrm{Pd}$ catalysts to study the active sites and adsorbed surface species. They found that the coexistence of $\mathrm{PdO} / \mathrm{PdO}^{\delta+}$ interface enhanced the activity of $\mathrm{CH}_{4}$ oxidation over the catalyst surface and this was independent of the support used. The DRIFTS analysis for $\mathrm{Pd} / \mathrm{Al}_{2} \mathrm{O}_{3}$ catalyst showed the presence of a $\mathrm{PdO} / \mathrm{PdO}^{\delta+}$ interface after surface activation which allowed the formation of formate and carbonate species.

Additionally, Hellman et al. ${ }^{39}$ investigated the active phase of Pd during methane oxidation using DFT calculations and in-situ surface XRD. The DFT calculations over a range of $\mathrm{Pd}$ and $\mathrm{PdO}_{\mathrm{x}}$ surfaces revealed that either coordinated $\mathrm{Pd}$ sites in $\mathrm{PdO}$ or $\mathrm{Pd}$ metallic surfaces were important for facile dissociation and adsorption of $\mathrm{CH}_{4}$, which is claimed to be the rate-limiting step for the methane oxidation reaction. Interestingly, and unambiguously, the experimental results obtained by SXRD suggested that high conversion of methane occurred over thick PdO (101) films and metallic Pd, which was consistent with the DFT calculations. The authors pointed out that the established link between high activity and atomic structure enabled rational design of improved catalysts.

In comparison with thermal conditions, non-thermal plasma processes have been shown to be able to overcome the kineticallyrestricted methane oxidation reaction at low temperatures ${ }^{17,22,40-}$ 43. Although there have been a few in-situ studies of plasma catalysis for different reactions ${ }^{22,44-46}$, there is only one example ${ }^{22}$ for the NTP-assisted methane oxidation over $\mathrm{Pd} / \mathrm{Al}_{2} \mathrm{O}_{3}$ catalyst. This study probed the role of NTP and the local Pd structure by direct monitoring of the catalyst by X-ray absorption fine structure (XAFS) coupled with end of pipe mass spectrometry. It revealed that the presence of the NTP did not significantly influence the structure of the Pd clusters but resulted in an increase in the temperature of the $\mathrm{Pd}$ nanoparticles. However, this differential heating was insufficient to initiate the thermal $\mathrm{CH}_{4}$ oxidation reaction which suggested that the NTP may play an important role in creating the new reaction pathways and/or assisting similar pathways as those under thermal conditions but with lower activation barriers.

In the present paper, the development of a new plug flow type plasma DRIFTS cell is described in details and applied to the investigation of the surface species present during the NTP-assisted methane oxidation over a $\mathrm{Pd} / \mathrm{Al}_{2} \mathrm{O}_{3}$ catalyst.

\section{Experimental}

\subsection{Catalyst preparation}

A 2 wt\% $\mathrm{Pd} / \mathrm{Al}_{2} \mathrm{O}_{3}$ catalyst was prepared by incipient wetness impregnation using $\left[\mathrm{Pd}\left(\mathrm{NO}_{3}\right)\right]_{2}$ (Johnson Matthey, Assay 15.3\%) as the palladium precursor and a SCFa $140 \mathrm{Al}_{2} \mathrm{O}_{3}$ (Sasol, BET $140 \mathrm{~m}^{2} \mathrm{~g}^{-1}$, moisture content $2.72 \%$ and pore volume $0.42 \mathrm{~cm}^{3} \mathrm{~g}^{-1}$ ) as the support. The palladium precursor was weighed and dissolved in $12.5 \mathrm{~cm}^{3}$ water which is just under the pore volume for the amount of support used. This aqueous solution was added dropwise to the alumina support under continuous stirring. A small amount of water (less than $1 \mathrm{~cm}^{3}$ ) was subsequently added via a pipette to the catalyst. The catalyst was dried at $105{ }^{\circ} \mathrm{C}$ overnight and calcined in static air at $600^{\circ} \mathrm{C}$ for $2 \mathrm{~h}$.

\subsection{In-situ DRIFTS-MS Experiments}

In-situ DRIFTS measurements were performed using a Bruker Vertex 70 FTIR spectrometer, equipped with a liquid $\mathrm{N}_{2}$-cooled mercury-cadmium-telluride (MCT) detector. A catalyst sample (50$70 \mathrm{mg}$ ) was placed in the ceramic crucible of the in-situ DRIFTS cell which outlet was connected to a Hiden Analytical HPR20 mass spectrometer via a heated capillary.

Prior to the in-situ DRIFTS measurements, the catalyst was pretreated to remove any adsorbed water and other adsorbed species by heating in flowing Ar with a total flow rate of $100 \mathrm{~cm}^{3} \mathrm{~min}^{-1}$ up to $120^{\circ} \mathrm{C}$ for $1 \mathrm{~h}$ and then cooled down to room temperature (RT). IR spectra were taken at RT under flowing $\mathrm{Ar}$ as background. For the plasma studies, the pre-treated catalyst was exposed to the reaction gas feed at RT for $10 \mathrm{~min}$ before switching on the plasma system. The power electrode was driven at $\sim 27 \mathrm{kHz}$ with applied peak voltages of 5 or $6 \mathrm{kV}$. Equations 1 and 2 were used to calculate the plasma power. The discharge electrical parameters were measured using a resistor (10 $\Omega$ ) for the current and a highimpedance probe (Tektronix, P6015) for the applied voltage, connected to a digital oscilloscope (Tektronix TBS1072B).

$$
\begin{array}{r}
\mathrm{P}_{\mathrm{ave}}=\frac{1}{\mathrm{~T}} \int_{0}^{T} I(t) V(t) d t \\
S I E=\frac{\mathrm{P}_{\text {ave }}}{\text { Total Flow Rate }}
\end{array}
$$

where $P_{a v e}$ is the average power, $t$ is time, $T$ is the cycle period, SIE is the specific input energy, $I$ is the current and $V$ is the voltage.

For comparison with the NTP-activated $\mathrm{CH}_{4}$ oxidation, the catalyst was tested under thermal activation. Prior to reaction, a pre-treatment under $\mathrm{Ar}$ was carried out at $300{ }^{\circ} \mathrm{C}$ and data correction included the background subtraction. The thermally activated reaction was carried out between 100 and $400{ }^{\circ} \mathrm{C}$ at a rate of $2{ }^{\circ} \mathrm{C} \mathrm{min}^{-1}$. For both the plasma and thermal tests, the gases for the reaction mixture were supplied by BOC, i.e. $5 \% \mathrm{CH}_{4} / \mathrm{Ar}$ (99.99\%), $\mathrm{O}_{2}$ (99.99\%) and $\operatorname{Ar}(99.999 \%)$ and each gas flow was individually controlled by an Aera ${ }^{\mathrm{TM}} \mathrm{FC}-7700 \mathrm{C}$ mass flow controller. The total flow rate of the gas mixture was $100 \mathrm{~cm}^{3} \mathrm{~min}^{-1}$. The concentrations of the reactants were 0.5 vol. $\% \mathrm{CH}_{4}, 10$ vol.\% $\mathrm{O}_{2}, 0.5$ vol.\% $\mathrm{Kr}$ and $\mathrm{Ar}$ as balance. End-of-pipe analyses were carried out with a Hiden Analytical HPR20 mass spectrometer (MS). The following mass-to-charge $(\mathrm{m} / \mathrm{z})$ ratios were monitored: $15\left(\mathrm{CH}_{4}\right), 16$ $\left(\mathrm{O}_{2}, \mathrm{CH}_{4}\right), 18\left(\mathrm{H}_{2} \mathrm{O}\right), 28(\mathrm{CO}), 32\left(\mathrm{O}_{2}\right), 44\left(\mathrm{CO}_{2}\right)$, and $82(\mathrm{Kr})$. Due to the contribution to the MS signal at $m / z=16$, of $\mathrm{H}_{2} \mathrm{O}$ and $\mathrm{O}_{2}, \mathrm{~m} / \mathrm{z}=$ 15 was used to monitor the $\mathrm{CH}_{4}$. The contribution of $\mathrm{CO}_{2}$ at $\mathrm{m} / z=$ 28 was accounted for and subtracted during data processing to extract the corrected CO signal. 
The IR spectra were recorded with a resolution of $4 \mathrm{~cm}^{-1}$ and an accumulation of 128 scans every $60 \mathrm{~s}$. The IR data is reported as log $1 / R$ ("absorbance") ${ }^{47}$, with $R=1 / I_{0}$, where $R$ is the sample reflectance, $I$ is the intensity measured under reaction conditions, and $I_{0}$ is the intensity measured on the sample under a flow of argon. The $l_{0}$ background spectrum was recorded at room temperature, immediately prior to the introduction of the reactants mixture.

\section{Results and Discussion}

\subsection{Design of the fixed bed plasma DRIFTS cell}

The newly designed plasma DRIFTS reactor aims to replicate as closely as possible the plug flow type reactor with the plasma discharge being generated across the catalyst bed between a central electrode positioned through the centre of the catalyst and a second one on the outside of the reactor.

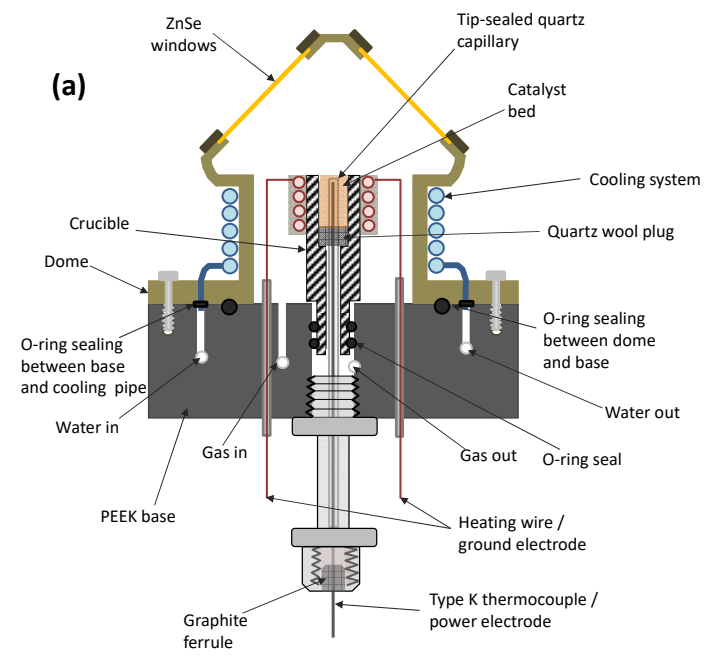

(b)

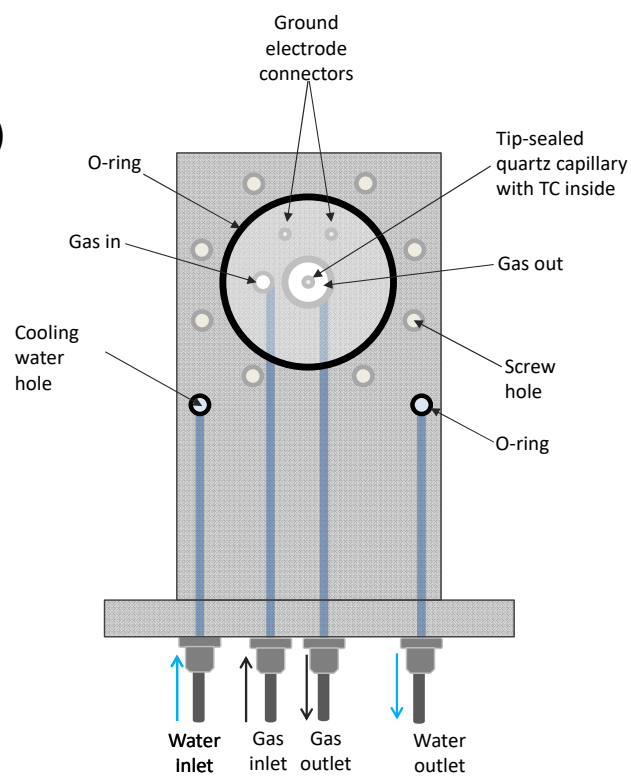

Figure 1 Schematic sketches of the plug flow plasma DRIFTS cell (a) and base (b).
The DRIFTS cell was composed of two major parts: (1) the base with crucible and (2) the dome with IR windows and cooling system. Figures 1 and 2 show the schematic drawings and photographs of the plug flow plasma DRIFTS cell, respectively.

The catalyst was contained in a ceramic $\left(\mathrm{MACOR}^{\circledR}\right)$ crucible. A $0.5 \mathrm{~mm}$ O.D. heating wire (Kanthal, supplied by Scientific Wire Company) was wrapped around the crucible and had a dual functionality: during the thermal tests or the catalyst pretreatments it ensured uniform heating of the catalyst; while during the plasma experiments, it was used as an (external) electrode. A Ktype thermocouple (TC, supplied by Omega Engineering Limited UK) was placed through the centre of the crucible and was enclosed in a tip-sealed quartz capillary to allow using it as a second (internal) electrode during the plasma tests. Excellent electrical insulation was required for both the heating wire and the thermocouple to prevent arc formation. To further control the discharge area and prevent arc generation, the metallic grid that was previously used to hold the powdered catalyst within the crucible ${ }^{25}$ was replaced with a quartz wool plug, as shown in Figure 1. To ensure no gas bypass was taking place, the crucible was tightly sealed to the base using two Viton O-rings (Figure 1a). Furthermore, a custom-made (PEEK) union fitting was designed to provide a gas-tight seal for the thermocouple to the base and keep it in place through the centre of the crucible (Figure 1a).
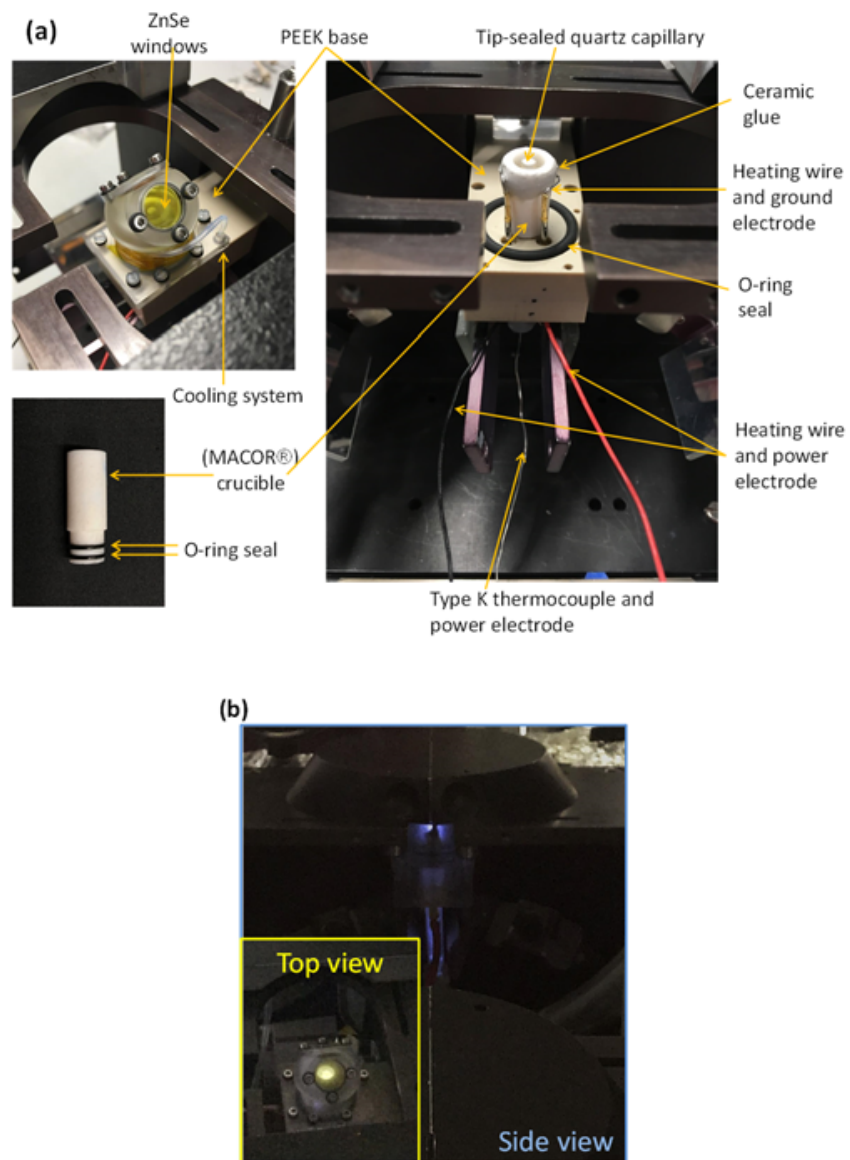

Figure 2 Photographs of DRIFTS cell components (a) and with the plasma on (b).

The DRIFTS base was designed to help with electrical insulation, while maintaining an excellent seal. Two materials have been tested 
and used for the manufacturing of the base: polymethyl methacrylate (Perspex) which was used during the setup of the plasma tests since it allowed the user to visualise where the discharge was produced; and polyether ether ketone (PEEK) due to its excellent thermal performance, as well as its chemical and wear resistance properties.

The base contained four channels: two were used for inlet and outlet of the gas feed and two others for water circulation around the dome, to prevent overheating of the ZnSe windows.

A newly developed dome was manufactured entirely from nonconducting materials (Perspex / PEEK) and fitted with ZnSe windows. Water was circulated on the outside of the dome through a Swagelok ${ }^{\circledR}$ perfluoroalkoxy (PFA) tubing to prevent overheating of the windows and formation of toxic hydrogen selenide. Additionally, an identical dome was manufactured of stainless steel for the thermal experiments/treatments. Viton O-rings were used to seal the dome to the base.

The outer dimensions of the new DRIFTS cell (Figures S1 and S2) were designed to ensure its compatibility with the Spectra-Tech ${ }^{\mathrm{TM}}$ beam collector. Figures S1 and S2 also provide the detailed dimensions of the custom-made base, ceramic crucible and dome.

\subsection{DRIFTS-MS investigation of the $\mathrm{CH}_{4}$ oxidation}

\subsubsection{MS analysis}

Figure 3 reports the changes in $\mathrm{CH}_{4}$ conversion as well as $\mathrm{CO}$ and $\mathrm{CO}_{2}$ formation as a function of the switching on and off of the plasma and as a function of the voltage applied over the $\mathrm{Pd} / \mathrm{Al}_{2} \mathrm{O}_{3}$ catalyst and the $\mathrm{Al}_{2} \mathrm{O}_{3}$ support in the absence of an additional heat source. For both samples, a few general observations can be made:

- when the plasma voltage was increased from 5 to $6 \mathrm{kV}$, the conversion of $\mathrm{CH}_{4}$ to $\mathrm{CO}$ and $\mathrm{CO}_{2}$ increased as expected.

- $\quad$ with the NTP on and regardless of the voltage applied, the initial conversion of $\mathrm{CH}_{4}$ and the initial formation of $\mathrm{CO}$ and $\mathrm{CO}_{2}$ instantly increased, and vice versa with NTP off. However, the profile of the $\mathrm{CH}_{4}$ conversion, the $\mathrm{CO}$ and $\mathrm{CO}_{2}$ formations were significantly different between the $\mathrm{Pd} / \mathrm{Al}_{2} \mathrm{O}_{3}$ and $\mathrm{Al}_{2} \mathrm{O}_{3}$ materials.

Figure 3 a shows that, at $5 \mathrm{kV}$, the $\mathrm{CH}_{4}$ conversion over the $\mathrm{Al}_{2} \mathrm{O}_{3}$ instantly increased to $18 \%$ but then gradually increased to $27 \%$ over the course of $27 \mathrm{~min}$ reaction time. Similarly, at $6 \mathrm{kV}$, the evolution of the MS profile showed a sudden increase in conversion of $\mathrm{CH}_{4}$ as soon as the NTP was switched on but then slowly increased from $33 \%$ to $42 \%$. It should be noted that the activity over the $\mathrm{Al}_{2} \mathrm{O}_{3}$ and blank empty DRIFTS reactor (Figure $3 c$ ) was not significantly different, showing a sudden increase followed by a slow but shorter change over $\sim 15 \mathrm{~min}$. This indicates that the gas phase reaction under NTP conditions occurs whether or not $\mathrm{Al}_{2} \mathrm{O}_{3}$ is present and it could be due to the dead volume of the DRIFTS cell above and underneath the catalyst bed. Thus, while the initial sharp increase in $\mathrm{CH}_{4}$ conversion is probably due to the gas phase reaction between $\mathrm{CH}_{4}$ and $\mathrm{O}_{2}$ in the plasma generated underneath the catalyst bed (Figure $2 \mathrm{~b}$ ), the slow increase in $\mathrm{CH}_{4}$ conversion may be due surface reactions on the $\mathrm{Al}_{2} \mathrm{O}_{3}$ support. Figure 3 a shows that the difference in $\mathrm{CO}$ and $\mathrm{CO}_{2}$ formation over $\mathrm{Al}_{2} \mathrm{O}_{3}$ at 5 and $6 \mathrm{kV}$ (corresponding to a SIE of $3.15 \mathrm{~kJ} \mathrm{~L}^{-1}$ and $4.32 \mathrm{~kJ} \mathrm{~L}^{-1}$, respectively) was not significant. The ratio of $\mathrm{CO}_{2}$ to $\mathrm{CO}$, calculated after $25 \mathrm{~min}$ exposure, was 0.95 and 1.22 for 5 and $6 \mathrm{kV}$, respectively. This trend is similar to that found in the NTP-assisted fixed bed reactor ${ }^{22}$.
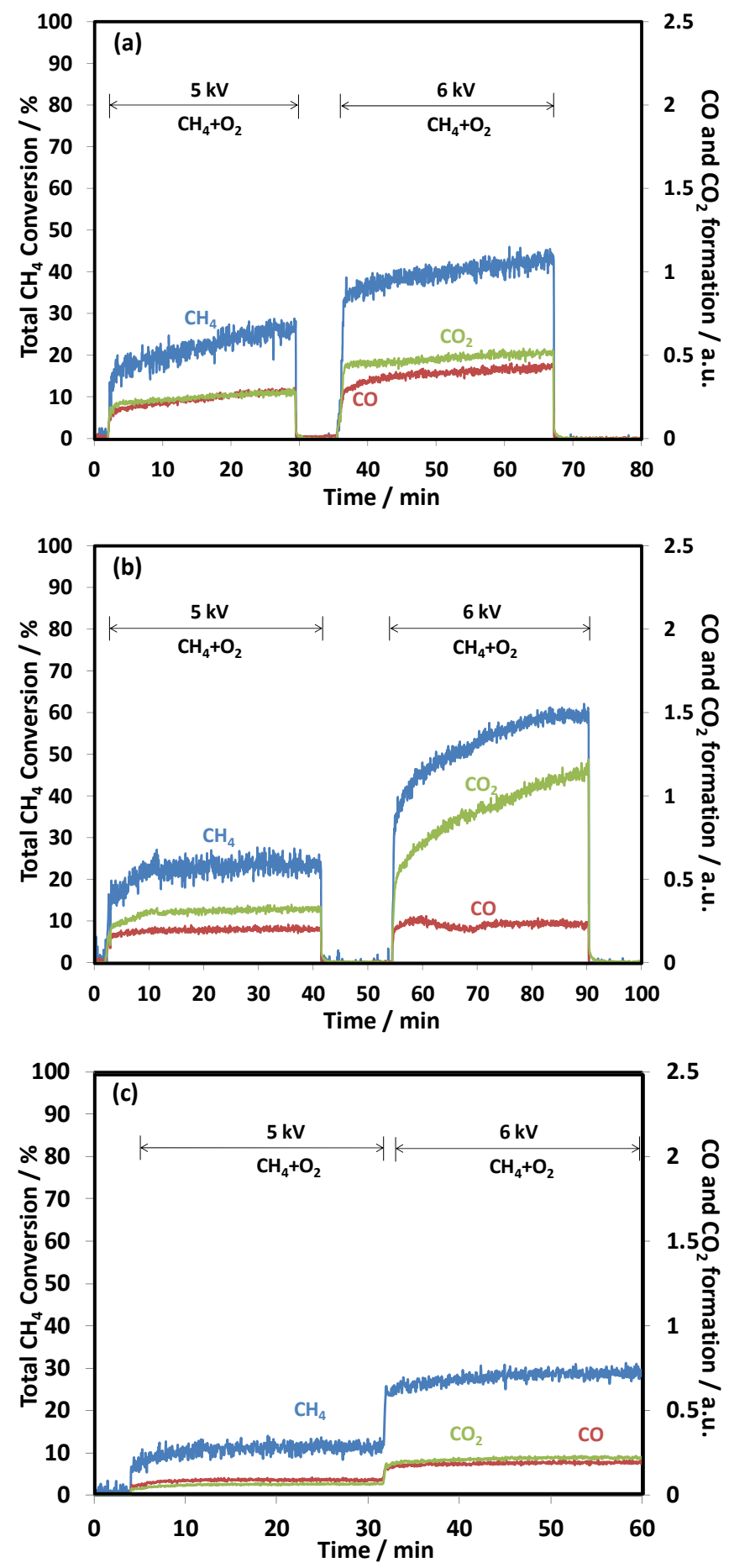

Figure 3 Changes in $\mathrm{CH}_{4}$ conversion, $\mathrm{CO}_{2}$ and $\mathrm{CO}$ formation as a function of plasma voltage applied to $\mathrm{Al}_{2} \mathrm{O}_{3}$ (a) $2 \% \mathrm{Pd} / \mathrm{Al}_{2} \mathrm{O}_{3}$ (b) and the empty reactor (c) under $0.5 \% \mathrm{CH}_{4}+10 \% \mathrm{O}_{2}$ reaction conditions.

Figure $3 \mathrm{~b}$ shows that the presence of $\mathrm{Pd}$ resulted in a slightly lower conversion at $5 \mathrm{kV}$ compared with the $\mathrm{Al}_{2} \mathrm{O}_{3}$ and a more steady activity with the conversion reaching $25 \%$ compared with $27 \%$ for the support alone. A small increase in the $\mathrm{CO}_{2}$ selectivity was observed for the $\mathrm{Pd} / \mathrm{Al}_{2} \mathrm{O}_{3}$ catalyst compared to the support on 
its own. The absence of significant difference, at $5 \mathrm{kV}$, when comparing to $\mathrm{Al}_{2} \mathrm{O}_{3}$, is probably due to the fact that there was insufficient energy available to activate the $\mathrm{Pd}$ catalyst. It also indicated that the gas phase reactions were dominant at this voltage (SIE of $2.95 \mathrm{~kJ} \mathrm{~L}^{-1}$ ). A substantial change was observed when increasing the voltage to $6 \mathrm{kV}$. The conversion increased to $60 \%$ over 35 minutes on stream, and a similar trend was observed for the production of $\mathrm{CO}_{2}$. The fact that this increase in performance was associated with a SIE decrease from $4.32 \mathrm{~kJ} \mathrm{~L}^{-1}$ for the test with $\mathrm{Al}_{2} \mathrm{O}_{3}$ to $3.5 \mathrm{~kJ} \mathrm{~L}^{-1}$ for the test with the Pd catalyst strongly suggests that the catalytic oxidation of $\mathrm{CH}_{4}$ over the $\mathrm{Pd} / \mathrm{Al}_{2} \mathrm{O}_{3}$ catalyst was promoted by the presence of $\mathrm{Pd}$. In contrast, the change in $\mathrm{CO}$ formation did not follow the same variation as for the $\mathrm{CH}_{4}$ conversion and $\mathrm{CO}_{2}$ formation. Figure $3 \mathrm{~b}$ shows that the $\mathrm{CO}$ formation profile at $6 \mathrm{kV}$ was relatively constant in time while the formation of $\mathrm{CO}_{2}$ significantly increased in line with the conversion of $\mathrm{CH}_{4}$. This suggested that the formation of $\mathrm{CO}$ took place via a different reaction pathway than that of $\mathrm{CO}_{2}$. This $\mathrm{CO}$ formation is likely predominantly taking place through gas phase reaction which is consistent with the somewhat small differences in $\mathrm{CO}$ production between the $\mathrm{Al}_{2} \mathrm{O}_{3}$ and $\mathrm{Pd} / \mathrm{Al}_{2} \mathrm{O}_{3}$ catalysts at 5 and $6 \mathrm{kV}$.

To examine the difference between the thermal and NTP activation of the catalyst, the methane oxidation was carried out using a fixed bed quartz reactor as reported elsewhere ${ }^{22}$. In the case of the thermal activation, Figure S3, it was evident that the catalytic combustion of methane occurred at high temperatures. The methane conversion started at $225{ }^{\circ} \mathrm{C}$ and reached $100 \%$ at $\sim 400{ }^{\circ} \mathrm{C} . \mathrm{Al}_{2} \mathrm{O}_{3}$ on its own showed very little activity with a conversion lower than $25 \%$ even at $400{ }^{\circ} \mathrm{C}$. This further confirmed the impact of the NTP on the low temperature methane oxidation.

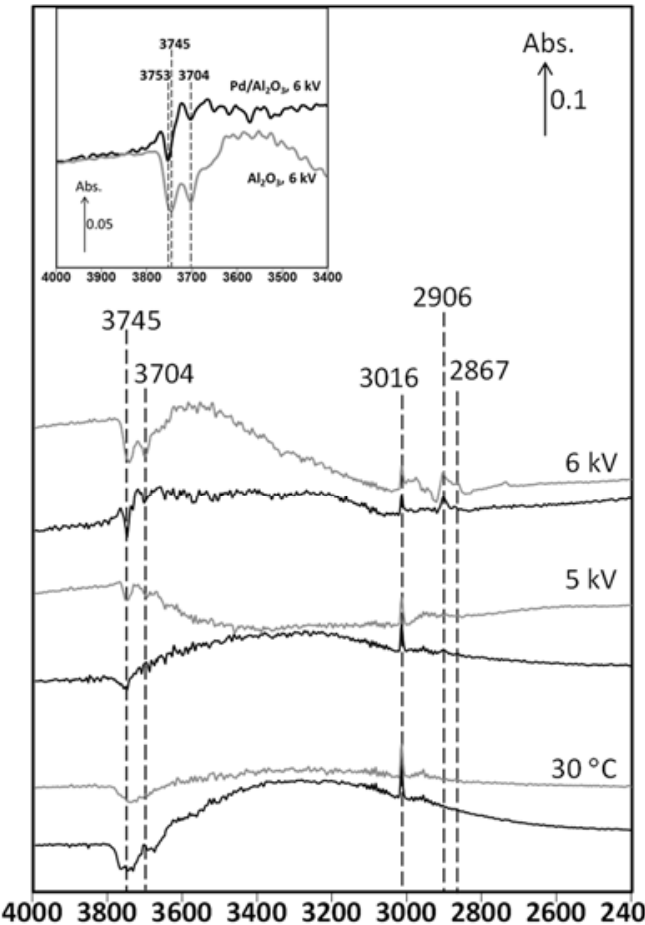

Wavenumber $/ \mathrm{cm}^{-1}$

\subsubsection{DRIFTS Analysis}

Figure 4 reports the comparison of DRIFT spectra recorded as a function of applied voltage over the $\mathrm{Al}_{2} \mathrm{O}_{3}$ support and the $\mathrm{Pd} / \mathrm{Al}_{2} \mathrm{O}_{3}$ catalyst. It should be noted that these spectra were obtained after 20 min under $\mathrm{CH}_{4}$ reaction conditions; the evolution as a function of time of the surface species at each voltage is included in the ESI (Figures S4-S7).

On applying the voltage to the system, an increase in adsorbed species is observed. It is interesting to note that the timing in changes of the DRIFT spectra was aligned with those of the gas phase $\mathrm{CH}_{4}, \mathrm{CO}_{2}$ and $\mathrm{CO}$, detected by mass spectrometer. The DRIFT spectra shown in Figure 4 indicates the presence of gas-phase $\mathrm{CH}_{4}$ ( $v_{\mathrm{C}-\mathrm{H}}$ at 3016 and $\delta_{\mathrm{C}-\mathrm{H}}$ at $\left.1304 \mathrm{~cm}^{-1}\right)^{34,35,48}$ and adsorbed $\mathrm{H}_{2} \mathrm{O}\left(\delta_{\mathrm{OHO}}\right.$ at $\left.1640 \mathrm{~cm}^{-1}\right){ }^{34}$. Both the $\mathrm{Al}_{2} \mathrm{O}_{3}$ support and the $\mathrm{Pd} / \mathrm{Al}_{2} \mathrm{O}_{3}$ catalyst showed similar infrared features at $30^{\circ} \mathrm{C}$.

At an applied peak voltage of $5 \mathrm{kV}$, new surface species were formed over the $\mathrm{Pd} / \mathrm{Al}_{2} \mathrm{O}_{3}$. The IR band at $1595 \mathrm{~cm}^{-1}$ is ascribed to the stretching vibration $v_{\mathrm{OcO}}$, derived from formate ( $\left.\mathrm{HCOO}^{-}\right)$) 33,35 . This is also confirmed by the appearance of the IR bands at 1393 and $1376 \mathrm{~cm}^{-1}$, due to the bending vibration $\left(\delta_{\mathrm{C}-\mathrm{H}}\right)$ from formate $33,35,37$. It should also be noted that, since the conversion of $\mathrm{CH}_{4}$ at 5 $\mathrm{kV}$ is low (see Figure 3), the $\mathrm{CH}_{4}$ species at 3016 and $1304 \mathrm{~cm}^{-1}$ exhibit very little change under NTP and $\mathrm{CH}_{4}$ reaction conditions.

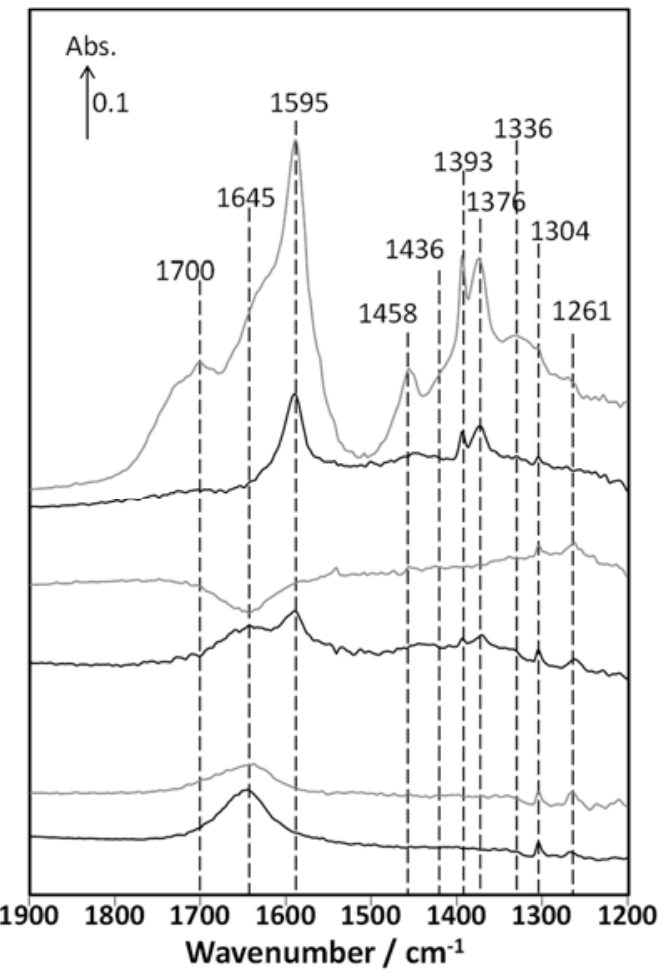

Figure 4 In-situ DRIFT spectra recorded as a function of plasma voltage applied to $\mathrm{Al}_{2} \mathrm{O}_{3}$ (grey) and $2 \% \mathrm{Pd} / \mathrm{Al}_{2} \mathrm{O}_{3}$ (black) after 20 min under $0.5 \% \mathrm{CH}_{4}+10 \% \mathrm{O}_{2}$ reaction conditions at ambient temperature. 
At $6 \mathrm{kV}$, an increase in $\mathrm{CH}_{4}$ conversion occurred (Figure 3) which also resulted in changes in the surface species over both the $\mathrm{Al}_{2} \mathrm{O}_{3}$ and the $\mathrm{Pd} / \mathrm{Al}_{2} \mathrm{O}_{3}$ catalyst (Figure 4). It is noticeable that, especially for the support, additional IR peaks at 2906, 2867, 1700, 1458, 1436 and $1336 \mathrm{~cm}^{-1}$ were detected. The IR bands at 2906 and $2867 \mathrm{~cm}^{-1}$ are ascribed to the stretching vibration of formate $\left(v_{\mathrm{C}-\mathrm{H}}\right)^{33,37}$. These IR bands coexist with the IR bands at 1393 and $1376 \mathrm{~cm}^{-1}$. In addition, the appearance of IR bands at 1700, 1646, 1436 and 1336 $\mathrm{cm}^{-1}$ are due to the formation of carbonate species ${ }^{35,49}$.

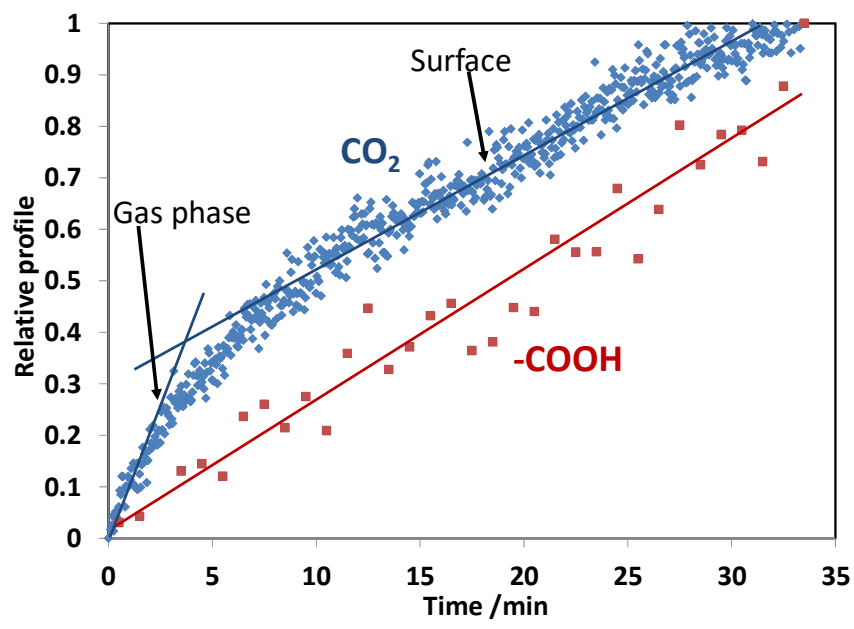

Figure 5 The correlation between $\mathrm{CO}_{2}(\mathrm{MS})$ and surface formate (DRIFTS) under NTP conditions at $6 \mathrm{kV}$ over $\mathrm{Pd} / \mathrm{Al}_{2} \mathrm{O}_{3}$ catalyst.

In order to establish more precisely a relationship between catalytic activity and surface species, a correlation between $\mathrm{CO}_{2}$ formation and surface formate at $6 \mathrm{kV}$ over $\mathrm{Pd}$ catalyst was examined. However, due to the significant contribution of the gas phase reaction between $\mathrm{CH}_{4}$ and $\mathrm{O}_{2}$ in the presence of NTP, a good fit was difficult to obtain. The initial increase of $\mathrm{CO}_{2}$ was predominantly associated with gas phase reaction and the passage through the catalyst bed to the MS, thereafter, the rate of increase in $\mathrm{CO}_{2}$ formation and the concentration of surface formate were similar which may be associated with the surface reaction under NTP conditions as shown in Figure 5.

It is also noteworthy that, at $6 \mathrm{kV}$, there are substantial differences between the $\mathrm{Al}_{2} \mathrm{O}_{3}$ support and the $\mathrm{Pd} / \mathrm{Al}_{2} \mathrm{O}_{3}$ catalyst with respect to the surface concentration of the adsorbed species. It has been found that surface carbonate and surface formate on $\mathrm{Al}_{2} \mathrm{O}_{3}$ support were observed, whereas there was little indication of surface carbonate over the $\mathrm{Pd} / \mathrm{Al}_{2} \mathrm{O}_{3}$ catalyst. In fact, the presence of NTP resulted in the significant formation of surface formate species under $\mathrm{CH}_{4}$ oxidation conditions over the $\mathrm{Pd} / \mathrm{Al}_{2} \mathrm{O}_{3}$ catalyst. Thus, the role of $\mathrm{Pd}$ at $6 \mathrm{kV}$ applied voltage might be to facilitate the activation of oxygen and favour the combustion of all formate species adsorbed on the support, both bidentate $\left(1592 \mathrm{~cm}^{-1}\right)$ and monodentate formates (bands above $1600 \mathrm{~cm}^{-1}$ ) that form at high coverages ${ }^{33,38,50,51}$. The increased exotherm would also facilitate $\mathrm{CO}_{2}$ (derived from carbonate) desorption.

Examining the IR region between 3800 and $3500 \mathrm{~cm}^{-1}$ in more detail, there were negative IR bands at 3772,3745 , and $3704 \mathrm{~cm}^{-1}$, assigned to hydroxyl groups on the surfaces $36,37,49$. However, it is interesting to note that significant differences in the hydroxyl groups under reaction conditions, especially for $6 \mathrm{kV}$, are observed between $\mathrm{Al}_{2} \mathrm{O}_{3}$ and $\mathrm{Pd} / \mathrm{Al}_{2} \mathrm{O}_{3}$. Figure 4 also shows that the $\mathrm{Al}_{2} \mathrm{O}_{3}$ support showed stronger negative IR bands between 3775 and $3700 \mathrm{~cm}^{-1}$ than the $\mathrm{Pd} / \mathrm{Al}_{2} \mathrm{O}_{3}$ catalyst, suggesting that there was a more substantial consumption of these hydroxyl species on the $\mathrm{Al}_{2} \mathrm{O}_{3}$. Föttinger et al. ${ }^{50}$ investigated the mechanism of carbonate formation over a $\mathrm{Pd} / \mathrm{Al}_{2} \mathrm{O}_{3}$ catalyst and confirmed that the interaction between $\mathrm{CO}$ and hydroxyl groups on the $\mathrm{Al}_{2} \mathrm{O}_{3}$ support resulted in the production of $\mathrm{HCOO}^{-}$species, which subsequently interacted with $\mathrm{O}_{2}$ to form carbonate species.

As noted earlier, the surface species adsorbed on the $\mathrm{Pd} / \mathrm{Al}_{2} \mathrm{O}_{3}$ catalyst under NTP and $\mathrm{CH}_{4}$ oxidation conditions mainly corresponded to formate species with a very small amount of adsorbed carbonate. Given that, at $6 \mathrm{kV}$, the transient profiles of both $\mathrm{CH}_{4}$ conversion and $\mathrm{CO}_{2}$ formation were similar upon turning the plasma on, but were different from that of $\mathrm{CO}$ formation, this would indicate that the formation of $\mathrm{CO}_{2}$ goes via a different route from that of $\mathrm{CO}$ formation. A similar behaviour is observed for the thermal case by Li et $a{ }^{38}$, who investigated the mechanism of $\mathrm{CH}_{4}$ oxidation reaction over a $\mathrm{Pd} / \mathrm{Al}_{2} \mathrm{O}_{3}$ catalyst by performing in-situ IR measurements under reaction conditions. It was reported that both $\mathrm{HCOO}^{-}$and $\mathrm{CO}_{3}{ }^{2-}$ intermediates were formed during the reaction, which subsequently decomposed to form $\mathrm{CO}$ and $\mathrm{CO}_{2}$, respectively ${ }^{38}$. The quasi absence of carbonate on the surface of the palladium catalyst under NTP exposure would indicate that their decomposition was promoted under these conditions. The surface formate may be associated with the reaction of $\mathrm{CO}$ interacting with surface hydroxyl groups as reported by Föttinger et al. ${ }^{50}$. 

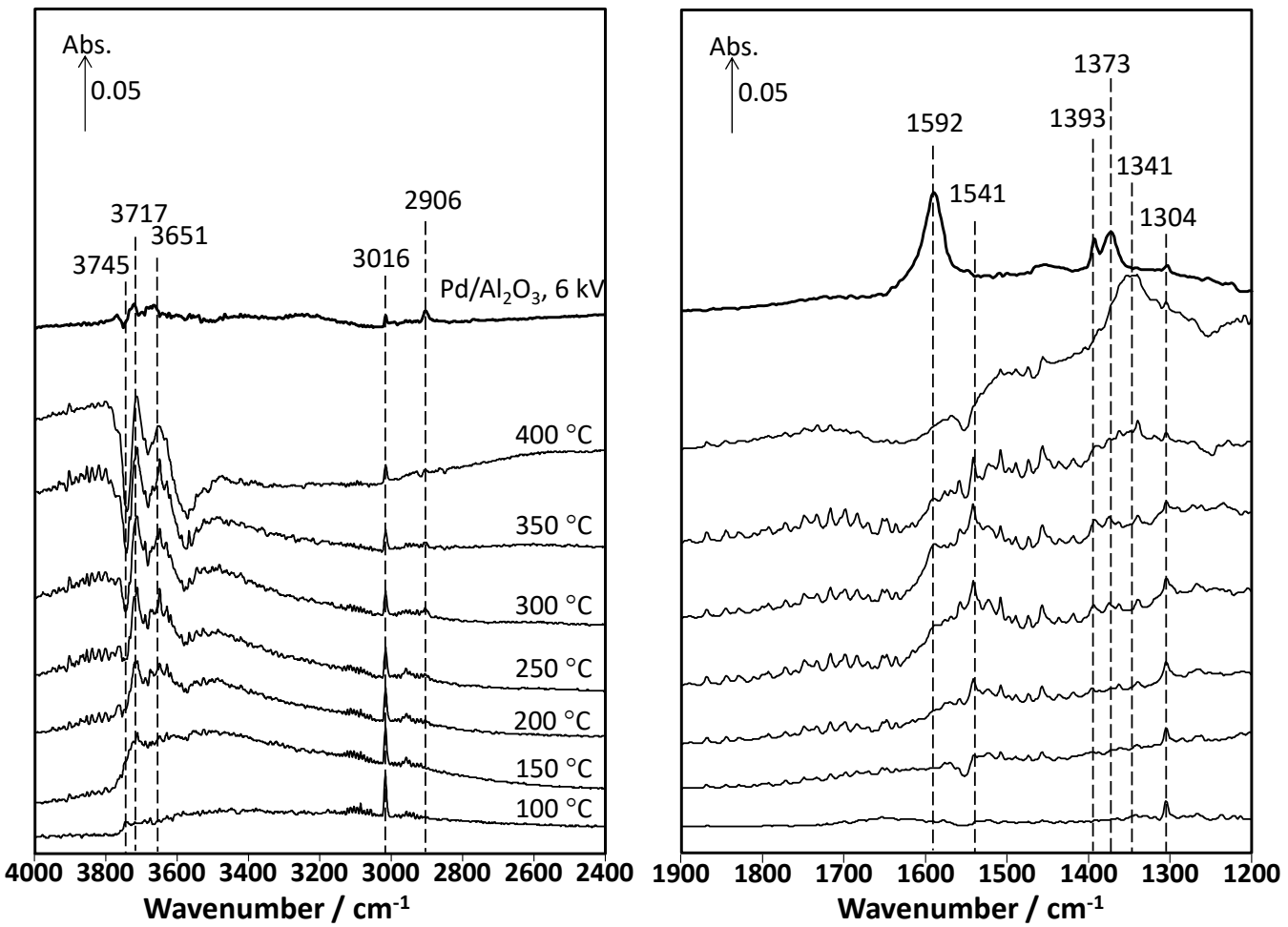

Figure 6 Comparison of in-situ DRIFT spectra recorded over $2 \% \mathrm{Pd} / \mathrm{Al}_{2} \mathrm{O}_{3}$ as a function of reaction temperature and plasma at ambient temperature at $6 \mathrm{kV}$ under $0.5 \% \mathrm{CH}_{4}+10 \% \mathrm{O}_{2}$ reaction conditions.

Gas phase reaction under plasma

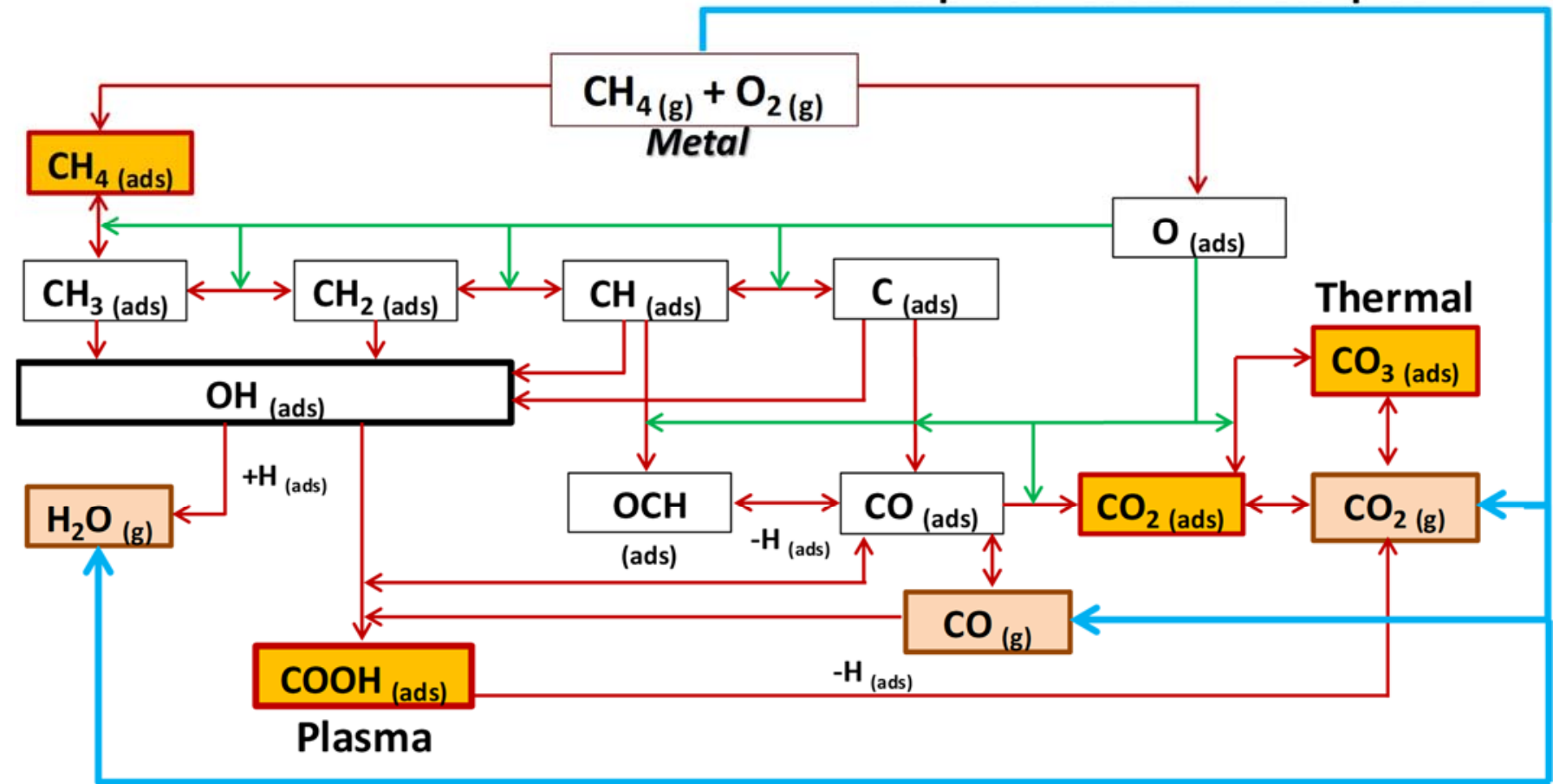

Figure 7 Schematic diagram representing the reaction mechanism of $\mathrm{CH}_{4}$ oxidation the possible pathways of $\mathrm{CO}_{2}$ formation under thermal and plasma conditions. 
To better understand the differences between NTP and thermal catalytic activation, in-situ DRIFTS measurement using a high temperature DRIFTS cell was carried out over the $\mathrm{Pd} / \mathrm{Al}_{2} \mathrm{O}_{3}$ catalyst. Figure 6 reports the comparison of the spectra recorded as a function of reaction temperature under thermal conditions with those recorded under NTP conditions at $6 \mathrm{kV}$. The DRIFTS results revealed that the distributions of surface species over the $\mathrm{Pd} / \mathrm{Al}_{2} \mathrm{O}_{3}$ catalyst under thermal conditions from 100 to $400{ }^{\circ} \mathrm{C}$ were significantly different to that obtained during the NTP-activated experiments. Figure 6 shows that the formation of surface formate $\left(2906,1592,1393 \text {, and } 1373 \mathrm{~cm}^{-1}\right)^{33,35,37}$ is predominant under NTP conditions while the majority of surface species under thermal conditions are carbonate (1541, and $\left.1341 \mathrm{~cm}^{-1}\right){ }^{35,50}$. This suggests that the reaction pathways for NTP and thermal conditions may be different, with the oxidation of $\mathrm{CH}_{4}$ to $\mathrm{CO}_{2}$ probably going via formate and carbonate routes, respectively.

The results obtained with the NTP activated $\mathrm{CH}_{4}$ oxidation can be rationalized (as shown in Figure 7) using the reaction mechanism reported in the literatures for high temperature thermal activation $31,33,35,36,38$. Following the methane and oxygen adsorption, methyl and $\mathrm{OH}$ groups are formed. Further reaction leads to the formation of $\mathrm{CH}_{\mathrm{x}}$ and $\mathrm{C}$ species, which can interact with adsorbed $\mathrm{O}$ to give $\mathrm{CO}, \mathrm{CO}_{2}$ and carbonate. Additionally, both gas phase and surface $\mathrm{CO}$ can interact with $\mathrm{OH}$ groups to form formate, which are subsequently decomposed to give $\mathrm{CO}_{2}$. According to our results, it is possible that the reaction takes mainly place via the carbonate route in the thermal case, while the oxidation occurs via the formate route under plasma conditions.

\section{Conclusions}

The new design of a plug flow type plasma DRIFTS reactor has been reported and evaluated through a model reaction i.e. the oxidation of methane over a $\mathrm{Pd} / \mathrm{Al}_{2} \mathrm{O}_{3}$ catalyst. Using the plasma DRIFTS cell coupled with mass spectrometry has allowed showing that NTP significantly enhances the formation of surface species, i.e. formate and carbonate, under methane oxidation conditions. Comparative analysis of the spectroscopic results with those obtained under thermal activation indicate that the reaction pathways for NTP and thermal conditions may be different.

\section{Conflicts of interest}

There are no conflicts to declare.

\section{Acknowledgements}

The current work was carried out as part of UK Catalysis Hub and the collaboration between the University of Manchester and Chiang Mai University. The UK Catalysis Hub is kindly thanked for resources and support via our membership of the UK Catalysis Hub Consortium and funded by EPSRC grant: EP/R026939/1, EP/R026815/1, EP/R026645/1, EP/R027129/1. K.W. and B.I. also would like to thank Science Achievement Scholarship of Thailand (SAST), Center of Excellence in Materials Science and Technology,
Chiang Mai University and Thailand Research Fund (the TRF Distinguished Research Professor Award to K. Grudpan, DPG6080002) for a partial financial support.

\section{References}

1 M. Schiavon, V. Torretta, A. Casazza and M. Ragazzi, Water, Air, Soil Pollut., 2017, 228, 388-408.

2 M. Bahri, F. Haghighat, S. Rohani and H. Kazemian, Chem. Eng. J., 2017, 320, 308-318.

3 A. Bogaerts and E. C. Neyts, ACS Energy Lett., 2018, 3, 1013-1027.

4 T. T. Gupta and H. Ayan, Appl. Sci., 2019, 9, 3548-3568.

$5 \quad$ Z. Abd Allah, J. C. Whitehead and P. Martin, Environ. Sci. Technol., 2014, 48, 558-565.

6 Q. H. Trinh and Y. S. Mok, Catalysts, 2015, 5, 800-814. 7 M. Laroussi and X. Lu, Appl. Phys. Lett., 2005, 87, 22-24. A. V. Nastuta, I. Topala, C. Grigoras, V. Pohoata and G. Popa, J. Phys. D. Appl. Phys., 2011, 44, 1-9.

9 H. H. Kim, Y. Teramoto, A. Ogata, H. Takagi and T. Nanba, Plasma Chem. Plasma Process., 2016, 36, 45-72.

10 V. Hessel, A. Anastasopoulou, Q. Wang, G. Kolb and J. Lang, Catal. Today, 2013, 211, 9-28.

11 T. Kuwahara, K. Yoshida, T. Kuroki, K. Hanamoto, K. Sato and M. Okubo, Plasma Chem. Plasma Process., 2014, 34, 65-81.

Z. Wang, H. Kuang, J. Zhang, L. Chu and Y. Ji, RSC Adv., 2019, 9, 5402-5416.

D. H. Lee, J. O. Lee, K. T. Kim, Y. H. Song, E. Kim and H. S. Han, Int. J. Hydrogen Energy, 2012, 37, 3225-3233.

14 W. S. Kang, D. H. Lee, J. O. Lee, M. Hur and Y. H. Song, Environ. Sci. Technol., 2013, 47, 11358-11362. Z. S. Zhang, C. Shi, Z. F. Bai, M. R. Li, B. B. Chen and M. Crocker, Catal. Sci. Technol., 2017, 7, 145-158. T. Wang, X. Zhang, J. Liu, H. Liu and B. Sun, React. Kinet. Mech. Catal., 2018, 124, 587-601.

A. Baylet, P. Marécot, D. Duprez, X. Jeandel, K. Lombaert and J. M. Tatibouët, Appl. Catal. B Environ., 2012, 113-114, 31-36.

C. E. Stere, W. Adress, R. Burch, S. Chansai, A. Goguet, W. G. Graham, F. De Rosa, V. Palma and C. Hardacre, ACS Catal., 2014, 4, 666-673.

19 R. Gholami Shahrestani, C. E. Stere, A. Goguet and C. Hardacre, Phil. Trans. R. Soc. A, 2017, 376, 1-21.

20 R. Matthes, I. Koban, C. Bender, K. Masur, E. Kindel, K. D. Weltmann, T. Kocher, A. Kramer and N. O. Hübner, Plasma Process. Polym., 2013, 10, 161-166.

21 V. Scholtz, J. Pazlarova, H. Souskova, J. Khun and J. Julak, Biotechnol. Adv., 2015, 33, 1108-1119. 
22 E. K. Gibson, C. E. Stere, B. Curran-McAteer, W. Jones, G. Cibin, D. Gianolio, A. Goguet, P. P. Wells, C. R. A. Catlow, P. 46 Collier, P. Hinde and C. Hardacre, Angew. Chemie - Int. Ed., 2017, 56, 9351-9355.

23 J. Kim, D. B. Go and J. C. Hicks, Phys. Chem. Chem. Phys., 2017, 19, 13010-13021.

24 C. E. Stere, J. A. Anderson, S. Chansai, J. J. Delgado, A. Goguet, W. G. Graham, C. Hardacre, S. F. R. Taylor, X. Tu, Z. Wang and H. Yang, Angew. Chemie - Int. Ed., 2017, 56, 5579-5583.

25 C. E. Stere, W. Adress, R. Burch, S. Chansai, A. Goguet, W. G. Graham and C. Hardacre, ACS Catal., 2015, 5, 956-964. P. Gélin and M. Primet, Appl. Catal. B Environ., 2002, 39, 137.

27 U. Thesis, , DOI:10.14288/1.0166751.

28 N. M. Kinnunen, J. T. Hirvi, K. Kallinen, T. Maunula, M. Keenan and M. Suvanto, Appl. Catal. B Environ., 2017, 207, 114-119.

R. J. Farrauto, J. K. Lampert, M. C. Hobson and E. M. Waterman, Appl. Catal. B, Environ., 1995, 6, 263-270. D. Ciuparu, E. Perkins and L. Pfefferle, Appl. Catal. A Gen., 2004, 263, 145-153.

31 W. R. Schwartz and L. D. Pfefferle, J. Phys. Chem. C, 2012, 116, 8571-8578. X. Cao, R. Zhou, N. Rui, Z. Wang, J. Wang, X. Zhou and C. jun Liu, Catal. Today, 2017, 297, 219-227.

33 H. Na, Z. Liu and T. Zhu, React. Kinet. Mech. Catal., 2014, 111, 137-148. M. C. Kung, S. S. Y. Lin and H. H. Kung, Top. Catal., 2012, 55, 108-115. M. Schmal, M. M. V. M. Souza, V. V. Alegre, M. A. P. da Silva, D. V. César and C. A. C. Perez, Catal. Today, 2006, 118, 392-401.

N. M. Martin, J. Nilsson, M. Skoglundh, E. C. Adams, X. Wang, G. Smedler, A. Raj, D. Thompsett, G. Agostini, S. Carlson, K. Norén and P. A. Carlsson, Catal. Struct. React., 2017, 3, 24-32. M. Richard, D. Duprez, N. Bion and F. Can, ChemSusChem, 2017, 10, 210-219.

Z. Li, G. Xu and G. B. Hoflund, Fuel Process. Technol., 2003, 84, 1-11.

A. Hellman, A. Resta, N. M. Martin, J. Gustafson, A. Trinchero, P. A. Carlsson, O. Balmes, R. Felici, R. Van Rijn, J. W. M. Frenken, J. N. Andersen, E. Lundgren and $\mathrm{H}$. Grönbeck, J. Phys. Chem. Lett., 2012, 3, 678-682. S. Da Costa, S. Carpentier, S. Capela, R. Marques and P. Da Costa, in International Gas Research Conference Proceedings, Elsevier, 2008, vol. 3, pp. 2327-2337.

41 B. Pietruszka, K. Anklam and M. Heintze, Appl. Catal. A Gen., 2004, 261, 19-24.

42 T. Pham Huu, S. Gil, P. Da Costa, A. Giroir-Fendler and A. Khacef, Catal. Today, 2015, 257, 86-92.

43 K. Konno, K. Onoe, Y. Takiguchi and T. Yamaguchi, Chem. Eng. Res. Des., 2015, 95, 144-149.

44 Z. Jia and A. Rousseau, Sci. Rep., , DOI:10.1038/srep31888.

45 M. Rivallan, E. Fourré, S. Aiello, J. M. Tatibouët and F. Thibault-Starzyk, Plasma Process. Polym., 2012, 9, 850-
854.

A. Rodrigues, J. M. Tatibouët and E. Fourré, Plasma Chem. Plasma Process., 2016, 36, 901-915.

47 J. Sirita, S. Phanichphant and F. C. Meunier, Anal. Chem., 2007, 79, 3912-3918.

48 G. Veser, J. Frauhammer, L. D. Schmidt and G. Eigenberger, Dynamics of Surfaces and Reaction Kinetics in Heterogeneous Catalysis, Proceedings of the International Symposium, Elsevier B.V., 1997, vol. 109. J. Szanyi and J. H. Kwak, Phys. Chem. Chem. Phys., 2014, 16, 15126-15138.

K. Föttinger, R. Schlögl and G. Rupprechter, Chem. Commun., 2008, 3, 320-322. H. Borchert, B. Jürgens, V. Zielasek, G. Rupprechter, S. Giorgio, C. R. Henry and M. Bäumer, J. Catal., 2007, 247, 145-154. 